\title{
UPAYA PENINGKATAN MOTIVASI, HASIL BELAJAR DAN RESPON SISWA MELALUI MODEL PEMBELAJARAN TIPE STUDENT TEAM ACHIEVEMENT DIVISION (STAD) PADA MATERI SUMPAH PEMUDA DI SMAN 4 TEBO
}

\author{
ERNAWATI \\ SMA Negeri 4 Kabupaten Tebo Provinsi Jambi \\ ernawati7238@yahoo.com
}

\begin{abstract}
ABSTRAK
Penelitian ini bertujuan (1) mengetahui peningkatan motivasi siswa kelas XI IPS 2 SMA Negeri 4 Tebo semester ganjil tahun pelajaran 2019/2020 melalui penerapan model pembelajaran kooperatif tipe Student Team Achievement Division (STAD) pada pelajaran Sejarah materi sumpah pemuda, (2) mengetahui peningkatan hasil belajar sejarah siswa kelas XI IPS 2 SMA Negeri 4 Tebo semester ganjil tahun pelajaran 2019/2020 melalui penerapan model pembelajaran kooperatif tipe Student Team Achievement Division (STAD), (3) mengetahui respon siswa kelas XI IPS 2 SMA Negeri 4 Tebo semester ganjil tahun pelajaran 2019/2020 terhadap penerapan model pembelajaran kooperatif tipe Student Team Achievement Division (STAD) pada pelajaran Sejarah materi sumpah pemuda. Penelitian ini merupakan jenis penelitian tindakan kelas (PTK). Tahap-tahap yang dilakukan dalam penelitian tindakan kelas (PTK) yaitu: (1) penentuan subjek penelitian, (2) membuat rencana tindakan, (3) melaksanakan tindakan, (4) melakukan observasi, (5) melakukan refleksi dan evaluasi. Hasil penelitian ini menunjukkan: (1) persentase rata-rata motivasi siswa kelas XI IPS 2 SMA Negeri 4 Tebo pada siklus I adalah 25,45\% dengan kategori tinggi, meningkat menjadi $26,33 \%$ pada siklus II dengan kategori tinggi; (2) rata-rata hasil belajar siswa kelas XI IPS 2 SMA Negeri 4 Tebo pada siklus I adalah 74,58 dengan kategori sedang, meningkat menjadi 83,54 pada siklus II dengan kategori tinggi; (3) respon siswa kelas XI IPS 2 SMA Negeri 4 Tebo terhadap penerapan model pembelajaran kooperatif tipe Student Team Achievement Division (STAD) mencapai kategori positif. Berdasarkan hasil penelitian ini dapat disimpulkan bahwa dengan penerapan model pembelajaran kooperatif tipe Student Team Achievement Division (STAD) dapat meningkatkan motivasi dan hasil belajar Sejarah materi sumpah pemuda siswa kelas XI IPS 2 SMA Negeri 4 Tebo semester ganjil tahun pelajaran 2019/2020 serta memperoleh respon yang positif.
\end{abstract}

Kata Kunci: model pembelajaran kooperatif tipe student team achievement division (STAD),motivasi, hasil belajar, respon, sumpah pemuda.

\section{PENDAHULUAN}

Pendidikan merupakan suatu kegiatan yang sistematis dan sistematik, terarah kepada terbentuknya kepribadian peserta. Pendidikan dikatakan sistematis karena proses pendidikan berlangsung melalui tahap berkesinambungan dan dikatakan sistematik karena berlangsung pada semua situasi kondisi dan semua lingkungan. Terlaksananya pendidikan melalui proses belajar mengajar pada dasarnya merupakan inti dari pendidikan secara keseluruhan, dimana guru sebagai pemegang peranan utama. Guru sebagai seorang siswa yang terlibat langsung dalam proses belajar mengajar, bertugas menciptakan kondisi belajar yang dapat membuat siswa belajar dengan optimal untuk mendapatkan prestasi belajar yang memuaskan (Wardani, dkk, 2017).

Sejarah merupakan cabang dari ilmu sosial yang mempelajari aspek ruang dan waktu dalam kehidupan manusia di masa lalu. Pembelajaran sejarah adalah perpaduan antara aktivitas belajar dan mengajar yang di dalamnya mempelajari tentang peristiwa masa lampau yang erat kaitannya dengan masa kini. Sejarah merupakan cabang ilmu pengetahuan yang menelaah tentang asal-usul dan perkembangan serta peranan masyarakat di masa lampau berdasarkan metode dan metodologi tertentu (Ulhaq, 2017). Terkait dengan pendidikan sejarah di sekolah dasar hingga sekolah menengah, pengetahuan masa lampau tersebut mengandung nilai-nilai kearifan yang dapat digunakan untuk melatih kecerdasan, membentuk sikap, watak dan kepribadian siswa. Sejarah adalah mata pelajaran yang menanamkan pengetahuan dan nilai- 
nilai mengenai proses perubahan dan perkembangan masyarakat Indonesa dan dunia pada masa lampau hingga kini. Jadi, mata pelajaran sejarah merupakan bidang studi yang berkaitan dengan fakta sejarah dengan tetap memperhatikan tujuan pendidikan pada umumnya (Khakim, 2018).

Mata pelajaran Sejarah memiliki arti strategis dalam pembentukan watak dan peradaban bangsa yang bermartabat serta dalam pembentukan manusia Indonesia yang memiliki rasa kebangsaan dan cinta tanah air. Melalui pelajaran sejarah siswa dapat melakukan kajian mengenai apa dan bila, mengapa, bagaimana, serta akibat apa yang timbul dari jawaban masyarakat bangsa di masa lampau tersebut terhadap tantangan yang mereka hadapi serta dampaknya bagi kehidupan pada masa sesudah peristiwa itu dan masa kini (Darmawan, 2019). Materi pendidikan sejarah mampu mengembangkan potensi siswa untuk mengenal nilai-nilai bangsa yang diperjuangkan pada masa lalu, dipertahankan dan disesuaikan untuk kehidupan masa kini, dan dikembangkan lebih lanjut untuk kehidupan masa depan. Bangsa Indonesia masa kini beserta seluruh nilai dan kehidupan yang terjadi adalah hasil perjuangan bangsa pada masa lalu dan akan menjadi modal untuk perjuangan kehidupan pada masa menatang (Siswati, dkk, 2018). Materi sejarah memberikan informasi mengenai keberhasilan dan kegagalan bangsa dalam menjawab tantangan zaman sehingga menjadi milik bangsa masa kini. Tindakan apa yang dilakukan para pelaku sejarah yang tidak berhasil mencapai tujuan dan perbuatan apa yang mereka lakukan yang berhasil mencapai tujuan. salah satu fungsi belajar sejarah untuk mengenal siapa diri kita sebagai bangsa dan kehilangan jatidiri berarti kehilangan eksistensi bangsa (Hasan, 2012).

Untuk mencapai tujuan dan fungsi ideal pendidikan dan pembelajaran Sejarah, dituntut adanya suatu inovasi dan perubahan pula pada pembelajaran Sejarah (Suryani, 2016). Kondisi ideal pembelajaran Sejarah yang diharapkan yaitu agar mengacu pada: (1) menggunakan pendekatan pembelajaran berbasis pada siswa aktif (active learning); (2) proses pembelajaran Sejarah juga diselenggarakan secara interaktif, inspiratif, menyenangkan, menantang, dan memotivasi siswa untuk berpartisipasi aktif, serta memberikan ruang yang cukup bagi prakarsa, kreativitas, dan kemandirian siswa sesuai dengan bakat, minat, dan perkembangan fisik serta psikologisnya; (3) secara lebih kongkrit proses pembelajaran dianjurkan terjadi dalam kelompok belajar yang heterogen dengan menggunakan model-model pembelajaran kooperatif (cooperative learning) (Susanto, 2019). Hal ini bertujuan agar adanya toleransi dan pengakuan atas perbedaan individual dan latar belakang budaya siswa.

Oleh karena itu, posisi guru (pengampu mata pelajaran Sejarah di SMA/MA, SMK/MAK) memiliki peran yang sangat penting. Guru Sejarah tidak lagi berperan sebagai pemberi informasi belaka tetapi juga berperan sebagai inovator, dinamisator, motivator dan fasilitator serta dituntut untuk memiliki wawasan yang luas dan kompeten dalam pembelajaran Sejarah (Susilo, dkk, 2019). Untuk itu di dalam pembelajaran Sejarah diperlukan model-model pembelajaran yang beraneka ragam serta metode sajian yang bervariasi (tidak monoton) yang mampu membangun motivasi belajar siswa dalam pembelajaran, menyenangkan hati siswa, menantang, dan memotivasi siswa untuk belajar sehingga nantinya akan bermuara pada peningkatan hasil belajar Sejarah siswa yaitu yang terbagi ke dalam tiga ranah yaitu sikap, pengetahuan, dan keterampilan (Oktafani, 2019).

Berdasarkan hasil observasi yang peneliti lakukan pada kelas XI IPS 2 SMA Negeri 4 Tebo menunjukkan bahwa proses pembelajaran di kelas selama ini yang terjadi cenderung menggunakan komunikasi satu arah, yaitu informasi hanya datang dari guru ke arah siswa, sehingga siswa menjadi kurang terlibat aktif dalam kegiatan pembelajaran. Dari beberapa penyebab rendahnya motivasi belajar tersebut yang dapat penulis catat adalah: (1) siswa kurang memperhatikan dalam proses pembelajaran; (2) penyampaian materi oleh guru kurang menarik; (3) kegiatan pembelajaran bersifat monoton yaitu ceramah dan mencatat; (4) guru belum memanfaatkan media pembelajaran yang sesuai dengan materi pelajaran. Motivasi belajar yang rendah berdampak pula pada hasil belajar sejarah berdasarkan data observasi awal dimana hasil belajar sejarah berada dibawah Kriteria Ketuntasan Minimal (KKM). Berdasarkan hasil Ulangan Tengah Semester I yang diperoleh siswa kelas XI IPS 2 SMA Negeri 4 Tebo, 
menunjukkan rata-rata nilai hanya 65,45 dari KKM 75 dengan nilai tertinggi 70, nilai terendah 60, dan persentase ketuntasan kelas $30 \%$.

Masalah di atas merupakan masalah yang sangat penting dan mendesak untuk dipecahkan dan dicarikan solusinya. Kondisi demikian apabila terus dibiarkan akan berdampak buruk terhadap kualitas dan hasil pembelajaran Sejarah. Permasalahan tersebut harus memerlukan penanganan secara profesional melalui penelitian tindakan kelas (PTK) (Sanjaya, 2016). Tindakan yang tepat untuk mengatasi permasalahan di atas, adalah perlu diterapkannya sebuah model pembelajaran yang mampu melibatkan siswa dalam proses pembelajaran, memberikan motivasi dan penghargaan dalam pembelajaran, mampu meningkatkan motivasi belajar siswa, serta membuat suasana pembelajaran yang menantang, merangsang siswa untuk belajar dan menyenagkan hati.

Salah satu model pembelajaran dengan prinsip-prinsip di atas yaitu model pembelajaran kooperatif tipe Student Team Achievement Division (STAD). Dimana, pembelajaran kooperatif tipe (STAD) ini merupakan sebuah kelompok strategi pengajaran yang melibatkan siswa bekerja secara berkolaborasi untuk mencapai tujuan bersama (Wijaya, 2018). Tujuan pembelajaran kooperatif disini adalah usaha untuk meningkatkan partisipasi siswa, memfasilitasi siswa dengan pengalaman sikap kepemimpinan dan membuat keputusan dalam kelompok, serta memberikan kesempatan pada siswa untuk berinteraksi dan belajar bersamasama siswa yang berbeda latar belakangnya. Jadi, dalam pembelajaran kooperatif siswa berperan ganda yaitu sebagai siswa ataupun sebagai guru. Dengan bekerja secara berkolaboratif untuk mencapai sebuah tujuan bersama, maka siswa akan mengembangkan keterampilan berhubungan dengan sesama manusia yang akan sangat bermanfaat bagi kehidupan di luar sekolah (Kusumawati, dkk, 2016).

Model pembelajaran kooperatif tipe Student Team Achievement Division (STAD) dipandang sangat relevan untuk mengatasi masalah pembelajaran pada mata pelajaran Sejarah untuk meningkatkan motivasi dan hasil belajar siswa kelas XI IPS 2 SMA Negeri 4 Tebo. Disamping itu juga model pembelajaran kooperatif tipe STAD ini memiliki keunggulan di antaranya, (1) siswa lebih mampu mendengarkan, menerima, dan menghormati serta menerima orang lain, (2) siswa mampu mengidentifikasi akan perasaannya juga perasaan orang lain, (3) siswa dapat menerima pengalaman dan dimengerti orang lain, (4) siswa mampu meyakinkan dirinya untuk orang lain dengan membantu orang lain dan meyakinkan dirinya untuk saling memahami dan mengerti, (5) siswa mampu mengembangkan potensi individu yang berhasil guna dan berdaya guna, kreatif, bertanggung jawab, mampu mengaktualisasikan, dan mengoptimalkan dirinya terhadap perubahan yang terjadi (Kristin, 2016).

Berbagai penelitian yang pernah dilakukan yang menunjukkan adanya peningkatan motivasi dan hasil belajar siswa dengan penerapan model pembelajaran kooperatif tipe Student Team Achievement Division (STAD) yaitu: pertama yaitu penelitian yang dilakukan oleh Canggih Dhermawan (2013) dengan judul "Penerapan Model Pembelajaran Kooperatif Tipe Student Teams Achievement Divisions (STAD) untuk meningkatkan kreativitas dan hasil belajar mata pelajaran sejarah siswa kelas XI Ilmu Sosial 2 SMA Negeri 3 Singraja tahun pelajaran 2012/2013”. Dalam penelitian ini dilaksanakan sebanyak dua siklus. Hasil penelitiannya menunjukkan kreativitas belajar dilihat dari rata-rata (Mean) pada siklus I menunjukan angka 66,75 sedangkan siklus II mennjukan ratarata 80,45 dengan demikian terdapat peningkatan rata-rata sebesar 13,7. Jadi dari penelitian tersebut terdapat peningkatan kreativitas dari siklus I sampai dengan siklus II. Hasil belajar siswa dilihat dari rata-rata (mean) siklus I menunjukan angka 74,35, sedangkan siklus II menunjukan rata-rata 81,9. Dengan demikian terdapat peningkatan 7,55. Maka dari penjelasan tersebut dapat dinyatakan bahwa dari siklus I sampai dengan siklus II terjadinya peningkatan hasil belajar.

\section{METODE PENELITIAN}

Jenis penelitian yang digunakan dalam penelitian ini adalah penelitian tindakan kelas (PTK) atau disebut classroom action research. Penelitian tindakan kelas adalah suatu bentuk 
penelitian yang bersifat reflektif dengan tindakan-tindakan tertentu agar dapat memperbaiki atau meningkatkan praktikpraktik pembelajaran. Dalam bentuk ini tujuan utama penelitian tindakan kelas adalah untuk meningkatkan praktek-praktek pembelajaran di kelas maupun di luar kelas (lapangan), guru terlibat secara penuh dalam proses perencanaan, aksi (tindakan), dan refleksi.

Tahap-tahap yang dilakukan dalam penelitian tindakan kelas (PTK) yaitu: (1) penentuan subjek penelitian, (2) membuat rencana tindakan, (3) melaksanakan tindakan, (4) melakukan observasi, (5) melakukan refleksi dan evaluasi. Sumber data pada penelitian ini terbagi menjadi data primer dan sekunder. Data primer yaitu nilai ulangan harian dan persentase motivasi siswa dalam pembelajaran sebelum dan sesudah diterapkannya tindakan. Sumber sekunder di luar subjek penelitian didapatkan dari hasil wawancara dengan guru mata pelajaran sejarah di SMA Negeri 4 Tebo dan hasil observasi peneliti.

Metode pengumpulan data dan instrumen yang digunakan dalam penelitian ini adalah metode wawancara, observasi, tes, dan kuisioner. Wawancara dilakukan terhadap guru Sejarah untuk mendapatkan gambaran situasi pembelajaran Sejarah materi sumpah pemuda di SMA Negeri 4 tebo secara umum dan di kelas XI IPS 2 secara khusus pada pra-siklus penelitian dan terhadap siswa untuk memperoleh tanggapan dan refleksi pelaksanaan tindakan. Wawancara menggunakan lembar pedoman wawancara. Observasi dilakukan untuk mendapatkan gambaran situasi pembelajaran Sejarah materi sumpah pemuda di kelas XI IPS 2 secara khusus pada prasiklus dan data motivasi siswa. Observasi menggunakan lembar pedoman observasi proses pembelajaran dan motivasi belajar siswa. Tes dilakukan untuk mendapatkan nilai hasil belajar siswa. Tes menggunakan tes soal objektif. Penyebaran kuisioner dilakukan untuk mendapatkan data respon siswa terhadap penerapan model pembelajaran kooperatif tipe Student Team Achievement Division (STAD). Metode kuisioner menggunakan lembar kuisioner respon siswa. Sedangkan dalam penelitian ini, teknik analisis data yang digunakan adalah analisis deskriptif kualitatif.

\section{HASIL DAN PEMBAHASAN}

\section{Siklus I}

Berdasarkan hasil analisis data siklus I didapatkan hasil sebagai berikut: (1) persentase rata-rata motivasi belajar siswa sebesar $25,45 \%$ yang berada pada kategori 'tinggi'; (2) nilai rata-rata hasil belajar siswa pada siklus I sebesar 74,58 yang berada pada kategori 'sedang' dengan ketuntasan belajar sebesar 50,00\%; (3) nilai rata-rata respon siswa terhadap model pembelajaran kooperatif tipe Student Team Achievement Division (STAD) yang didapatkan sebesar 33,91, maka berdasarkan kategori respon siswa terhadap penerapan model pembelajaran kooperatif tipe Student Team Achievement Division (STAD) berada pada kategori 'Cukup positif'.

Selama pembelajaran siklus I, berdasarkan hasil refleksi terhadap pelaksanaan tindakan siklus I, adapun beberapa hal yang terlihat yang menghambat kelancaran proses pembelajaran antara lain (1) Pada pertemuan awal siswa masih terlihat bingung karena belum terbiasa dengan model pembelajaran yang diterapkan yaitu belajar berkelompok dan menuangkan materi yang dipelajari dalam bentuk kooperatif tipe Student Teams Achievement Divisions (STAD). Hal ini terjadi karena selama ini mereka lebih banyak belajar secara konvensional yaitu hanya dengan mendengarkan penjelasan guru dan mengerjakan soal-soal latihan yang diberikan guru. (2) Pada saat pembagian kelompok, guru (peneliti) membagi siswa dalam 4 kelompok secara heterogen. Masing-masing kelompok terdiri dari 4-6 orang. Siswa menuju ke kelompoknya masing-masing dalam suasana gaduh dan sempat menolak ketika kelompok yang tidak sesuai dengan keinginannya. (3) Dalam diskusi masih terdapat siswa yang enggan untuk berdiskusi dengan temannya saat menjawab pertanyaan-pertanyan yang diberikan oleh guru. Siswa yang memiliki kemampuan akademik tinggi belum terbiasa membimbing teman anggota kelompoknya yang memiliki kemampuan akademik kurang, begitu pula siswa yang mempunyai kemampuan akademik kurang, masih tidak berani atau malu untuk mengungkapkan 
pendapatnya, sehingga kegiatan diskusi belum berjalan secara optimal karena masih banyak siswa yang belum dapat bekerja sama untuk menyelesaikan permasalahan yang diberikan oleh guru (peneliti). (4) Sulitnya menguasai kelas saat siswa berdiskusi dalam kelompoknya, karena jika tidak diperhatikan mereka akan mengganggu teman/kelompok lainnya dan mengerjakan kegiatan lain saat proses pembelajaran berlangsung. Sebagian besar siswa belum terbiasa menyimpulkan konsep-konsep yang telah dipelajari. (5) Siswa masih mengalami kesulitan dalam membuat simpulan yang sistematis dan sesuai dengan yang diharapkan. (6) Proses pembelajaran yang dilakukan dengan model pembelajaran kooperatif tipe Student TeamsAchievement Divisions (STAD) membutuhkan waktu yang lebih banyak, agar semua siswa bisa menuangkan imajinasi/pendapatnya dan ketika melakukan tanya jawab siswa bisa menjawab. Mengingat waktu yang disediakan sangat terbatas, maka pengaturan waktu yang tepat sangat diperlukan agar proses pembelajaran bisa berjalan sesuai dengan yang telah direncanakan.

Adapun perbaikan-perbaikan yang dilakukan dari hasil refleksi siklus I yaitu (1) Mensosialisasikan kembali model pembelajaran kooperatif tipe Student Teams-Achievement Divisions (STAD) pada setiap pertemuan dengan menyampaikan kepada siswa mengenai manfaat dan langkah-langkah dari model pembelajaran yang diterapkan. Hal ini bertujuan untuk mendorong siswa agar lebih tertarik dan tidak kebingungan lagi dalam mengikuti kegiatan pembelajaran yang diterapkan sehingga pertemuan berikutnya siswa lebih antusias dan terbiasa dalam mengikuti pembelajaran. (2) Sebelum melaksanakan tindakan siklus II, siswa ditekankan kembali mengenai proses pembelajaran yang diterapkan, lebih mengutamakan aktivitas siswa secara optimal di dalam kelas. Siswa diberi kesempatan untuk dapat melakukan langkah-langkah model pembelajaran kooperatif tipe Student Teams-Achievement Divisions (STAD) secara lebih optimal. Guru hanya berperan sebagai fasilitator dan mediator serta salah satu sumber belajar melainkan bukan satu-satunya sumber belajar. (3) Memberikan motivasi kepada setiap siswa/kelompok tentang pentingnya kerjasama dalam diskusi. Guru juga lebih aktif menjadi fasilitator seperti memberikan bimbingan yang lebih intensif kepada kelompok yang mengalami kesulitan selama diskusi berlangsung. Selain itu, guru juga memotivasi siswa untuk tidak malu dalam mengemukakan pendapat mereka dalam diskusi kelompok. (4) Siswa ditekankan kembali bahwa setiap langkah pembelajaran yang dilakukan oleh siswa akan diobservasi oleh guru yang akan dijadikan sebagai bahan penilaian siswa. Semua siswa dalam kelompok diharapkan melakukan aktivitas dan setiap anggota kelompok betanggung jawab atas keberhasilan kelompok dan anggota kelompoknya. Guru juga menekankan bahwa setiap anggota kelompok yang memberikan pertanyaan, tanggapan, kritik, saran ataupun jawaban yang disampaikan ketika proses pembelajaran berlangsung itu semua dinilai oleh guru. (5) Guru membimbing dan mengarahkan siswa dalam membuat kesimpulan dengan memberikan pertanyaan pancingan yang mengarah pada simpulan yang diharapkan. Setiap siswa diberikan kesempatan untuk menanggapi kesimpulan temannya dan mencatatnya, begitu pula dengan guru yang akan menyempurnakan jika kesimpulan siswa kurang tepat.

\section{Siklus II}

Berdasarkan hasil analisis data siklus II didapatkan hasil sebagai berikut: (1) persentase rata-rata motivasi belajar siswa meningkat menjadi $26,33 \%$ berada pada kategori 'tinggi'; (2) nilai rata-rata hasil belajar siswa meningkat menjadi 83,54 berada pada kategori 'tinggi' dengan ketuntasan belajar siswa sebesar 83,33\%; (3) nilai rata-rata respon siswa sebesar 36,75, maka berdasarkan kategori respon siswa terhadap penerapan model pembelajaran kooperatif tipe Student Team Achievement Division (STAD) berada pada kategori 'positif'.

Setelah dilakukannya tindakan perbaikan pada pembelajaran siklus II, berdasarkan pengamatan yang dilakukan selama siklus II terlihat motivasi, hasil belajar dan ketuntasan belajar siswa mengalami perkembangan yang baik. Refleksi yang telah dilakukan terhadap penerapan model pembelajaran kooperatif tipe Student Team Achievement Division (STAD) sangat baik dilakukan. Adapun temuan dalam refleksi ini adalah sebagai berikut: (1) Meningkatkan kerjasama dan interaksi siswa dalam belajar. (2) Memberikan kesempatan 
kepada siswa untuk mengemukakan pendapat dan bertanya mengenai materi yang belum jelas atau kurang dipahami. (3) Secara umum proses pembelajaran siswa telah dapat berjalan sesuai dengan rencana pelaksanaan pembelajaran yang dilaksanakan. Kondisi dan situasi belajar siswa pada setiap pertemuan sudah menunjukkan situasi belajar yang kondusif jika dibandingkan dengan pertemuan-pertemuan pada siklus I. Setiap siswa dalam kelompok telah menunjukkan adanya kesungguhan dan antusiasme dalam berdiskusi. Guru dapat melakukan penelitian secara optimal terhadap semua aktivitas siswa, karena siswa telah dapat menunjukkan tahapan tahapan belajar sesuai dengan rencana pelaksanaan pembelajaran yang telah direncanakan oleh guru (peneliti). (4) Aktivitas siswa selama proses pembelajaran pada siklus II telah menunjukkan peningkatan yang lebih baik dibandingkan dengan proses pembelajaran pada siklus I. Siswa secara aktif telah mau secara sadar melaksanakan setiap tahapan pembelajaran dan melaksanakan diskusi tanpa menunggu intruksi dari guru. Setiap kelompok dapat menunjukkan rasa solidaritasnya untuk dapat mencapai hasil belajar yang lebih baik.

\section{Pembahasan}

Melihat dari hasil penelitian siklus I dan siklus II menunjukkan adanya peningkatan motivasi, hasil belajar dan respon siswa terhadap penerapan model pembelajaran kooperatif tipe Student Team Achievement Division (STAD). Untuk data peningkatan motivasi, hasil belajar dan respon siswa dapat dilihat pada tabel 01 .

Tabel 1. Hasil Penelitian Siklus I dan Siklus II

\begin{tabular}{|c|c|c|c|}
\hline No & Variabel & $\begin{array}{l}\text { Siklus } \\
\text { I }\end{array}$ & $\begin{array}{l}\text { Siklus } \\
\text { II }\end{array}$ \\
\hline \multirow[t]{2}{*}{1} & Motivasi Siswa & $25,45 \%$ & $26,33 \%$ \\
\hline & Kategori & Tinggi & Tinggi \\
\hline \multirow[t]{2}{*}{2} & Hasil Belajar & $74,58 \%(74,58)$ & $83,54 \%(83,54)$ \\
\hline & Kategori & Sedang & Tinggi \\
\hline 3 & Ketuntasan Belajar & $50,00 \%$ & $83,33 \%$ \\
\hline \multirow[t]{3}{*}{4} & Respon Siswa & 33,91 & 36,75 \\
\hline & Kategori & Cukup Positif & Positif \\
\hline & $\begin{array}{c}\text { Rata-rata } \\
\text { Kategori }\end{array}$ & \multicolumn{2}{|c|}{$\begin{array}{c}35,33 \\
\text { Positif }\end{array}$} \\
\hline
\end{tabular}

Peningkatan persentase rata-rata motivasi siswa kelas XI IPS 2 SMA Negeri 4 Tebo pada siklus I yaitu 25,45\% dengan kategori tinggi, meningkat menjadi $26,33 \%$ pada siklus II dengan kategori tinggi. Meningkatnya motivasi siswa tidak terlepas dari model pembelajaran yang diterapkan oleh peneliti yaitu dengan menerapkan model pembelajaran kooperatif tipe STAD. Model pembelajaran kooperatif tipe STAD mampu mengembangkan sikap bekerjasama dan berfikir siswa (Trianto, 2009:127-128). Siswa lebih aktif dalam mengikuti proses pembelajaran, melakukan interaksi dengan teman dalam suatu proses pembelajaran, sehingga siswa akan lebih senang belajar dan pembelajaran tidak membosankan (Hamalik, 2008:68, Dimyati \& Mudjiono, 2006:44).

Meningkatnya hasil belajar siswa dari siklus I yaitu 74,58 dengan kategori sedang dengan ketuntasan belajar sebesar 50,00\%, meningkat menjadi 83,33 pada siklus II dengan kategori sangat tinggi dengan ketuntasan belajar 83,33\%, menunjukkan bahwa teori yang dikemukakan oleh (Hamalik, 2008:68, Dimyati \& Mudjiono, 2006:44) Siswa lebih aktif dalam mengikuti proses pembelajaran, melakukan interaksi dengan teman dalam suatu proses pembelajaran, sehingga siswa akan lebih senang belajar dan pembelajaran tidak membosankan, Timbulnya kerjasama antar siswa dengan siswa, tim atau teman sehingga dapat menyelesaikan tugas yang diberikan di dalam kelompoknya masing-masing (Hamalik, 2008:91, dan Depdiknas, 2006:163). Rasa percaya diri siwa dalam melakukan suatu tugas yang diberikan 
oleh guru (Dimyanti \& Mudjiono, 2006:245, dan Depdiknas, 2006:163). Model pembelajaran kooperatif tipe STAD ini merupakan sebuah kelompok strategi pengajaran yang melibatkan siswa bekerja secara berkolaborasi untuk mencapai tujuan bersama. Tujuan pembelajaran kooperatif disini adalah usaha untuk meningkatkan partisipasi siswa, memfasilitasi siswa dengan pengalaman sikap kepemimpinan dan membuat keputusan dalam kelompok, serta memberikan kesempatan pada siswa untuk berinteraksi dan belajar bersama-sama siswa yang berbeda latar belakangnya. Jadi, dalam pembelajaran kooperatif siswa berperan ganda yaitu sebagai siswa ataupun sebagai guru. Dengan bekerja secara berkolaboratif untuk mencapai sebuah tujuan bersama, maka siswa akan mengembangkan keterampilan berhubungan dengan sesama manusia yang akan sangat bermanfaat bagi kehidupan di luar sekolah. Sesuai dengan penelitian sebelumnya yang dilakukan oleh Canggih Dermawan (2013) dapat meningkatkan kreativitas dan hasil belajar mata pelajaran sejarah.

Berdasarkan hasil analisis persentase rata-rata nilai respon siswa dari silus I ke siklus II terhadap penerapan model pembelajaran kooperatif tipe Student Team Achievement Division (STAD) diperoleh nilai rata-rata 35,33 dengan kategori 'positif'.

\section{KESIMPULAN}

Berdasarkan hasil penelitian dan pembahasan, maka dapat disimpulkan hal-hal sebagai berikut: (1) Penerapan model pembelajaran kooperatif tipe Student Teams-Achievement Divisions (STAD) dapat meningkatkan motivasi belajar siswa kelas XI IPS 2 SMA Negeri 4 Tebo pada mata pelajaran Sejarah materi sumpah pemuda. Ini dapat dilihat dari hasil siklus I jumlah motivasi siswa mencapai 611 dengan rata-rata mencapai 25,45. Jika dilihat dari kriteria penggolongan tingkat motivasi belajar siswa, berada diantara 22,5 $\leq(\overline{\mathrm{x}})<27,5$ yang berarti motivasi belajar siswa "tinggi". Pada siklus II jumlah motivasi siswa mencapai 632 dengan rata-rata 26,33. Jika dilihat dari kriteria penggolongan tingkat motivasi belajar siswa, berada diantara 22,5 $\leq(\overline{\mathrm{X}})<27,5$ yang berarti motivasi belajar siswa "tinggi". Peningkatan motivasi dari siklus I ke siklus II adalah 19 dengan rata-rata peningkatan mencapai 7,9\%. (2) Penerapan model pembelajaran kooperatif tipe Student TeamsAchievement Divisions (STAD) dapat meningkatkan hasil belajar siswa kelas XI IPS 2 SMA Negeri 4 Tebo pada mata pelajaran Sejarah materi sumpah pemuda. Ini dapat dilihat dari hasil belajar siklus I, jumlah semua nilai yang didapat dari 34 orang siswa adalah 1790 dengan rata-rata 74,58, rata-rata persen 74,58\% dan ketuntasan belajar mencapai 50,00\%. Jika dibandingkan dengan pedoman PAP skala Lima berada pada rentangan 65-79 yaitu kategori "sedang". Pada siklus II jumlah semua nilai yang didapat dari 34 orang siswa adalah 2005 dengan rata-rata 83,54, ratarata persen 83,54\% dan ketuntasan belajar mencapai 83,33\%. Jika dibandingkan dengan pedoman PAP Skala 5 berada pada rentangan 80-89 yaitu kategori "tinggi". Peningkatan hasil belajar siswa dari siklus I ke siklus II adalah 215 , dengan peningkatan rata-rata 8,95 , peningkatan rata-rata persen $8,95 \%$ dan peningkatan ketuntasan belajar siswa mencapai 33,33\%. (3) Respon / tanggapan siswa kelas XI IPS 2 SMA Negeri 4 Tebo terhadap penerapan model pembelajaran kooperatif tipe Student Teams-Achievement Divisions (STAD) pada siklus I adalah 814 dengan rata-rata 33,91. Jika dilihat dari kriteria penggolongan tingkat respon siswa berada diantara $25 \leq \overline{\mathrm{X}}<35$, yang berarti tanggapan siswa terhadap penerapan model pembelajaran kooperatif tipe Student TeamsAchievement Divisions (STAD) berada pada kategori "cukup positif”. Pada siklus II respon siswa terhadap penerapan model pembelajaran kooperatif tipe Student Teams-Achievement Divisions (STAD) meningkat menjadi "positif". Ini dapat dilihat dari hasil penyebaran angket respon siswa mencapai 882 dengan rata-rata 36,75 . Jika dilihat dari kriteria penggolongan tingkat respon siswa, berada diantara $35 \leq \overline{\mathrm{X}}<45$, yang berarti tanggapan siswa masuk dalam kategori "positif". Peningkatan respon siswa yang terjadi dari siklus I ke siklus II adalah sebesar 68 dengan rata-rata mencapai 2,83. (4) Dengan adanya peningkatan motivasi belajar dan hasil belajar siswa kelas XI IPS 2 SMA Negeri 4 Tebo, maka penerapan model pembelajaran kooperatif tipe Student Teams-Achievement Divisions (STAD) di kelas XI IPS 2 SMA Negeri 4 
Tebo pada mata pelajaran Sejarah materi sumpah pemuda semester ganjil tahun pelajaran 2019/2020 dikatakan berhasil.

\section{DAFTAR PUSTAKA}

Canggih Dhermawan ketut. 2013. Penerapan Model Pembelajaran Kooperatif Tipe Student TeamsAchievement Divisions (STAD) untuk meningkatkan kreativitas dan hasil belajar mata pelajaran sejarah siswa kelas XI Ilmu Sosial 2 SMA Negeri 3 Singraja tahun pelajaran 2012/2013. Undiksha. Singaraja - Bali

Darmawan, W. (2019). Pendidikan Nasionalisme Dalam Penulisan Buku Teks Pelajaran Sejarah Sekolah Menengah Atas Masa Orde Baru Dan Reformasi Di Indonesia (Doctoral dissertation, Universitas Pendidikan Indonesia).

Hasan, S. H. (2012). Pendidikan sejarah untuk memperkuat pendidikan karakter. Paramita: Historical Studies Journal, 22(1).

Khakim, M. N. L. (2018). Telaah Penulisan Karya Sastra Sejarah sebagai Refleksi Sumber Pembelajaran Sejarah. Sejarah dan Budaya: Jurnal Sejarah, Budaya, dan Pengajarannya, 10(1), 89-94.

Kristin, F. (2016). Efektivitas Model Pembelajaran Kooperatif Tipe STAD Ditinjau Dari Hasil Belajar IPS Siswa Kelas 4 SD. Scholaria: Jurnal Pendidikan dan Kebudayaan, 6(2), 74-79.

Kusumawati, H., \& Mawardi, M. (2016). Perbedaan Penerapan Model Pembelajaran Kooperatif Tipe NHT dan STAD Ditinjau dari Hasil Belajar Siswa. Scholaria: Jurnal Pendidikan dan Kebudayaan, 6(3), 251-263.

Oktafani, A. (2019). Peran guru sejarah dalam membentuk sikap nasionalisme siswa di SMAN 8 Padang (Doctoral dissertation, Universitas Negeri Padang).

Sanjaya, D. H. W. (2016). Penelitian tindakan kelas. Prenada Media.

Siswati, S., Utomo, C. B., \& Muntholib, A. (2018). Implementasi Pendidikan Karakter dalam Membentuk Sikap dan Perilaku Sosial Siswa Melalui Pembelajaran Sejarah di SMA PGRI 1 Pati Tahun Pelajaran 2017/2018. Indonesian Journal of History Education, 6(1), 1-13.

Suryani, N. (2016). Pengembangan media pembelajaran sejarah berbasis it. Jurnal Sejarah dan Budaya, 10(2), 186-196.

Susanto, H., \& Akmal, H. (2019). Media Pembelajaran Sejarah Era Teknologi Informasi (Konsep Dasar, Prinsi Aplikatif, dan Perancangannya).

Susilo, A., \& Isbandiyah, I. (2019). Peran Guru Sejarah dalam Pembentukan Pendidikan Karakter Anak Era Globalisasi. Indonesian Journal of Social Science Education (IJSSE), 1(2), 171-180.

Ulhaq, Z. (2017). Pembelajaran Sejarah Berbasis Kurikulum 2013 di SMA Kotamadya Jakarta Timur. Jurnal Pendidikan Sejarah, 6(2), 49-60.

Wardani, K. W., Loekmono, L., \& Supramono, S. (2017). Keterlaksanaan Standar Pengelolaan Pendidikan Di Sma Terakreditasi. Kelola: Jurnal Manajemen Pendidikan, 4(1), 1227.

Wijaya, H., \& Arismunandar, A. (2018). Pengembangan Model Pembelajaran Kooperatif Tipe STAD Berbasis Media Sosial. Jurnal Jaffray, 16(2), 175-196. 